\title{
A REVIEW ON THE POTENTIAL OF TURBULENT CONTACT ABSORBER FOR AIR POLLUTION CONTROL
}

\author{
Durga Jeevitha S. ${ }^{1}$, Annam Renita A. ${ }^{2}$, Soundarajan Krishnan ${ }^{3}$, Abbas Mohaideen J. ${ }^{4}$ \\ ${ }^{1}$ Research Scholar, Dept. of Chemical Engineering Sathyabama University, Chennai, India \\ ${ }^{2,3}$ Department of Chemical Engineering Sathyabama University, Chennai, India \\ ${ }^{4}$ Mamallan Institute of Technology, Sriperumbudur, India \\ E-mail : 'durgajeevitha@yahoo.co.in
}

\begin{abstract}
The utility industry today finds itself confronted with two opposing crises: A cleaner environment versus increased energy requirement. Federal and local governments are pressuring industry to substantially reduce its stack emission to the environment. The concentration of the gaseous pollutants also influences local climatic conditions and lead to global warming. Flue gases emitted due to combustions of heavy oils and coal, boiler and power plants contain toxic gaseous pollutants like Oxides of sulfur (Sox), Oxides of Nitrogen $\left(\mathrm{No}_{\mathrm{x}}\right)$, carbon monoxide $(\mathrm{CO})$, Hydrogen Sulfide $\left(\mathrm{H}_{2} \mathrm{~S}\right)$ etc., A treatment before being discharged into the atmosphere is vital for safe environment. A Turbulent Bed Contactor (TBC) is an excellent air pollution control device, which is used as wet scrubber for the simultaneous removal of pollutant gases. TBC possess significant advantages such as the ability to operate at large gas and liquid throughputs without plugging and the possibility of obtaining high heat and mass transfer rates. Because of its tremendous turbulence and mixing characteristics self-cleaning is possible without much scale formation and it offers high scrubbing efficiency. The process consists of a scrubber, a hold tank and a liquid solid separator. The process involve sodium based absorption of sulfur dioxide followed by reaction outside the scrubber with lime and /or limestone to produce a solid calcium sulfite /sulfate waste in excess and regenerated sodium scrubber feed solutions. Pollutants gases removal in excess of $95 \%$ can be easily achieved and lime utilization higher than $95 \%$ attained. The system operating conditions can be controlled to produce a solid waste containing low levels of dissolved solids and good handling characteristics.
\end{abstract}

KEYWORDS : Turbulent bed contactor, Air Pollution, Wet Scrubber

\section{INTRODUCTION}

Most economic activities, involving the use and conversion of energy and industrial activities like combustion of heavy oil and coal, smelting operations, manufacture of sulphuric acid plants and metallurgical processes. Emit toxic and pollutant gases thus degrading the environment and in particular the urban environment.

Urban air pollution is the source of a range of problems, including health risks of a range of problems, including health risks with inhalation of gases and particles accelerated corrosion and deterioration of materials, damage to historical monuments and buildings and damage to vegetation in the environment. A Turbulent Bed Contactor (TBC) has been demonstrated as a simple and effective wet scrubbing device for the removal of gaseous pollutants at a commercial scale since mid-1970. A Turbulent Bed Contactor (TBC) is a three phase countercurrent fluidized bed with gas serving as the continuous phase. It can operate at a large gas throughput without plugging.

\section{TURBULENT BED CONTACTOR HISTORY}

A turbulent bed fluid absorption system brings mass, heat and particle transfer into the $21^{\text {st }}$ century. This gas cleaning technology is been in practice since the early
1970 's. In that time people have installed well over one hundred scrubber plants using the fluidized bed principles in many countries including notably three UK, Germany ,USA. Where the market is generally most receptive to advancement in process technologies.

\section{UNIQUE FEATURES OF TURBULENT BED CONTACTOR}

The features include good gas-solid contact, excellent mass transfer and heat transfer characteristics essentially isothermal conditions in the reaction zone, close atmosphere control, extensive heat storage volume, vigorous mixing and agitation. These attributes either individually or collectively make fluidized - solids technology favorable for pollution control.

\section{Air Pollution Problems:}

As one of the main atmospheric acidifiers, sulphur dioxide is the worst culprit in the destruction of buildings and other objects of historical and cultural heritage. Nitrogen dioxide is emitted due to the combustion of various fuels such as natural gas, coal and oil. It causes respiratory illness and damage to lung tissue and contributes to acid rain and smog. It also corrodes stone buildings, statues and monuments including ancient sites of cultural heritage. When emanating from combustion 
process, $\mathrm{CO}_{2}$ sources may be well defined print sources such as the stacking plants, chimneys in a city but also forest or the burning of organic residues. It causes nausea, .Fossil fuel combustion also gives off sometimes known as black smoke. Soot consists of extremely fine carbon-containing particles that in addition to being health hazard are responsible for the blackening of buildings and other outdoor structures in many cities.

\section{METHODOLOGY}

The process consist of a scrubber, a hold tank and a liquid -solid separator. Lime and limestone slurry are typical absorbents used in the wet scrubbing process. A Turbulent Bed Contactor enables excellent contact between the particulate laden flue gas and the absorbents ( scrubbing medium ). There are three basic types of throwaway process - simple slurry, double -alkali and slurry with soluble additives. In the simple slurry process the waste gas is scrubbed with a slurry of product solids and unreacted limestone. In the double alkali process sulfur dioxide is absorbed into a clear solution of soluble alkali like sodium sulfite or ammonium sulfite and then with lime or limestone. Slurry scrubbing with soluble additives is a hybrid of simple slurry and the double alkali process. The process uses soluble alkalis or buffers as does the double alkali process and also recycles slurry to the scrubber as does the simple slurry process . Double alkali process with soluble additives gives more rapid rates and larger capacities for pollutant gas mass transfer than does a simple slurry process and slurry scrubbing with soluble additives. Double alkali process was taken up for extensive study.

The basic chemical reactions occurring are as follows:

Scrubber reactions

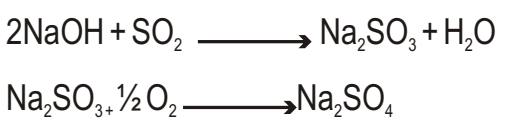

Reaction tank reactions

$$
\begin{aligned}
& \mathrm{Na}_{2} \mathrm{SO}_{3+} \mathrm{Ca}(\mathrm{OH})_{2}+1 / 2 \mathrm{H}_{2} \mathrm{O} \longrightarrow \mathrm{CaSO}_{3} \cdot 1 / 2 \mathrm{H}_{2} \mathrm{O}+2 \mathrm{NaOH} \\
& \mathrm{Na}_{2} \mathrm{SO}_{4+} \mathrm{Ca}(\mathrm{OH})_{2}+2 \mathrm{H}_{2} \mathrm{O} \longrightarrow \mathrm{CaSO}_{4} \cdot 2 \mathrm{H}_{2} \mathrm{O}+2 \mathrm{NaOH}
\end{aligned}
$$

Oxidation of the sodium sulfite as indicated by the reaction occurs to a certain extent in the scrubber due to the presence of excess air in the flue gas. Additional oxidation occurs in the recycle of the scrubbing fluid back to the scrubber. Consequently some sodium sulfite will be formed which will have to be removed from the system preferably as gypsum as is shown in the reaction.

Studies are conducted using a TBC with Dc/ dp (diameter of column/ diameter of particle) $>10$ to overcome wall effects. The effect of downcomer is to be studied for advantages such as pressure drop reduction and to increase the range of operation of a TBC. Multistage studies is conducted to eliminate channeling of the liquid phase and bypassing of the gas phase. Pollutant gases and particulates are monitored and measured quantitatively using online gas analyzer. The unique nonclogging feature of the TBC ensures reliable and consistent operation without any increase in gas side pressure drop.The system is integrated with the plant process control system to ensure optimum operation.

TBC's high mass transfer performance allows for fabrication of compact towers thereby helping to minimize space requirements \& capital costs.

\section{TURBULENT BED CONTACTOR FOR POLLUTION CONTROL}

The logical use of fluidization for pollution control is in general, as a gaseous phase, high temperature oxidization unit to burn combustible content of organic containing wastes or to oxidize or decompose chemical wastes. In both cases the offensive or toxic polluting components are destroyed or converted into innocuous compounds. This has been termed ultimate disposal in that no residual polluting material is produced. This has been proposed in distribution to those treatment procedures where a residual sludge or other material remains in the treatment process itself, the residual material is a pollutant and must eventually be disposed of in some manner .

By product recovery can, in many cases, represent a cost compensating advantage of oxidative fluidized solids waste control process. This can take the form of chemical recovery where the waste contains one or more residual components, relatively free of diluent materials, which are valuable or useful in the form in which they are obtained from the process, or it can take the form of thermal recovery where steam, hot water, or hot gases are available from the thermal energy released during the processing.

By the very manner in which the combustion air is introduced to a fluidized bed, control of the atmosphere for oxidation reactions is quite simple. The efficiency of TBC is quite high even at relatively low excesses of combustion air. The amount of free oxygen in the exhaust gases can be varied simply by changing the mass flow of fluidizing air to the unit. This allows extensive latitude in maintaining the required oxidation potential within the fluidized bed for any particular application and enhances complete combustion with the elimination of smoke and odor. This is particularly important in order to prevent atmospheric pollution. Pollutant gases removal in excess of $95 \%$ can be easily 
achieved and lime utilization higher than 95\% attained. The system operating conditions can be controlled to produce a solid waste containing low levels of dissolved solids and good handling characteristics.

\section{COMMERCIAL APPLICATION}

\begin{tabular}{|c|c|}
\hline APPLICATION & PERFORMANCE \\
\hline $\begin{array}{l}\mathrm{SO}_{2} / \mathrm{Particle} \\
\text { scrubbing with } \\
\text { process heat } \\
\text { recovery on a toxic } \\
\text { waste incinerator. }\end{array}$ & $\begin{array}{c}>99 \% \mathrm{SO}_{2} \text { removal and } \\
>90 \% \text { particulate } \\
\text { removal @ }<1.2 \mathrm{~mm} \\
\text { size. }\end{array}$ \\
\hline $\begin{array}{l}\text { Soot/zinc oxide } \\
\text { particle scrubbing of } \\
\text { furnace fumes }\end{array}$ & $\begin{array}{c}>90 \% \text { particulate } \\
\text { removal @ < } 1 \mathrm{~mm} \text { size. }\end{array}$ \\
\hline $\begin{array}{l}\text { Sodiumoxide } \\
\left(\mathrm{Na}_{2} \mathrm{O}\right) \text { fine particle } \\
\text { crubbing from } \\
\text { reactor }\end{array}$ & $\begin{array}{c}80-90 \% \text { particulate } \\
\text { removal @ 0.6mm size. }\end{array}$ \\
\hline $\begin{array}{l}\text { HF and fine particle } \\
\text { scrubbing of } \\
\text { aluminum smelter } \\
\text { fumes }\end{array}$ & $\begin{array}{c}99 \% \text { HF removal \& } 90 \% \\
\text { particulate removal @ } \\
<2 \mathrm{~mm} \text { size. }\end{array}$ \\
\hline $\begin{array}{l}\mathrm{H}_{2} \mathrm{~S} \& \text { crystalline } \\
\text { particle scrubbing } \\
\text { from chemical } \\
\text { reactor }\end{array}$ & $\begin{array}{c}>99.99 \% \mathrm{H}_{2} \mathrm{~S} \\
\text { absorption whilst } \\
\text { maintained clog free. }\end{array}$ \\
\hline $\begin{array}{l}\text { NOx scrubbing from } \\
\text { pharmaceutical } \\
\text { continuous reactors }\end{array}$ & $\begin{array}{l}\text { NOx removal using } \\
\mathrm{NaOH} 50-70 \% \text { range. }\end{array}$ \\
\hline $\begin{array}{l}\text { NOx scrubbing from } \\
\text { metal recovery } \\
\text { process }\end{array}$ & $\begin{array}{l}>70 \% \text { NOx removal } \\
\text { with } \mathrm{NaOH} \text {. }\end{array}$ \\
\hline $\begin{array}{l}\mathrm{HCl} \& \text { fine particle } \\
\text { scrubbing from } \\
\text { clinical waste } \\
\text { incinerator gases }\end{array}$ & $\begin{array}{c}>99.9 \% \mathrm{HCl} \text { removal } \\
\text { with }>90 \% \text { particle } \\
\text { removal @ <2mm size. }\end{array}$ \\
\hline
\end{tabular}

\section{CONCLUSION}

The industrial effluent gases especially the combustion gases emitted into the atmosphere are toxic and noxious substances. A treatment before being discharged into the atmosphere is vital for a safe environment. Flue gases containing pollutant gases and dust particles can be treated before discharging into the atmosphere effectively by a TBC which will help meet the requirements and specifications of Pollution Control Board or Environmental Protection Agency. All Indian industries can adopt this innovative technology to combat growing pollution problems and thus have a pollution free environment.

\section{REFERENCES}

[1] M.Epstein, and F.T.Princiotta, "Operating experience with a prototype lime-limestone scrubbing test facility", AIChE Symposium series, Vol.70, (1972).

[2] S.S.Storm, and W.Downs, ," A systematic approach to limestone scrubbing ",AlChE Symposiums series, Vol.71, (1973).

[3] Neil.H.Coats and Richard.L.Rice"Sulfur dioxide reduction by combustion of coals in fluidized beds", AIChE Symposium series, Vol.71, (1973).

[4] S.C.Wang, M.Epstein et.al. "Limestone test results at the EPA alkali wet-scrubbing test facility at the TVA Shawnee power plant ," AIChE Symposium series, Vol.71,(1973.)

[5] G.T Rochelle and C.J.King ," The effect of additives on mass transfer in calcium carbonate or calcium oxide slurry scrubbing of sulfur dioxide form waste gases", Ind .Chem. Engg. Vol.16,. (1977).

[6] A.V Slack," Lime-limestone scrubbing-Design considerations, 'CEP, (1978).

[7] G.T.Rochelle and C.J.King." Alternatives for stack gas desulfurization by throwaway scrubbing ," CEP(1978).

[8] M.Miconnet, P.Guigon, J.FLarge," The scrubbing of acid gases in columns with fixed or mobile packings, " International Chemical Engg. Vol.22, (1982).

[9] Soudarajan Krishnan, Ph.d Thesis, "Hydrodynamics of single and multi-stage TBC with and without downcomer, (1995).

[10] S.Kriesz,H.Hunsinger,H.Vogg,"Wet scrubbers-A potential pollution control source ", Chemosphere, Vol.32, (1996).

[11] A.E.R,Bruce, P.S.T Sai,,K.Krishnaiah, "Liquid phase mixing in a Turbulent Bed Contactor ",Chemical Engg.Science, (2003).

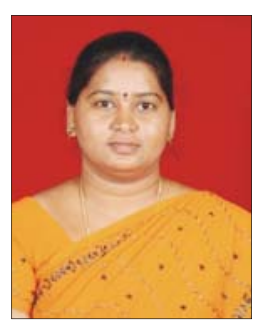

Ms. Durga Jeevitha .S is working as a Faculty in the Department of Chemical Engineering in Sathyabama University. She has four years of research experience and her research interests are Air Pollution and Control and Fluidization Engineering. 